LIVING POETRY: FIVE RUMINATIONS

Carl Leggo, University of British Columbia 


\section{LIVING POETRY: FIVE RUMINATIONS}

A poet stands before reality that is every day new, miraculously complex, inexhaustible, and tries to enclose as much of it as possible in words. (Milosz 56)

I am currently living in a cottage in York Harbour, Newfoundland, on sabbatical leave, faraway from my typical hectic, urban life in Vancouver, British Columbia. I am daily aware of the privilege of sabbatical living, and in this place I am focusing on rural rhythms and sensual living. I devote a part of each day to poetry, and I am learning again a lesson I have often learned in the past: poetry invites me to breathe, to attend, to slow down, to embrace the healing of body and spirit and imagination. I recently turned fifty years old, and from this liminal space I am reviewing the past and learning to live with a keener appreciation for each day's bounty. Like Jeanette Winterson, I am seeking to understand "the importance of poetry and its function in a healthy society" (76).

As a poet and language educator, I am often asked, Is this a good poem?, as if I carry some kind of standard measuring device for assessing the value of poems. (Certainly, many reviewers and editors are confident that they have the standard measure for evaluating poetry, and often remind me that my own poems are not very good!) But, perhaps the important question is not, Is this a good poem?, but instead, What is a poem good for? Barbara Kingsolver claims that "poems are everywhere, but easy to miss" (229). In the privileged position of sabbatical living in a little town on the edge of the North Atlantic Ocean, I am attending to autumn light and winter light, moonlight and snowlight, and the play of mist and fog and occasional sunlight. I am listening to the wind, and noting the ways that gulls and crows enter the wind, even sometimes hang still, suspended in a boisterous snowstorm. And I am attending to language, too, and especially how language shapes and animates knowing and understanding. So, in this paper, I offer five reasons why poetry is important for living. Of course, there are many more reasons that could be discussed, but my goal is to contribute to an ongoing dialogue among language educators about the value of living poetry in our personal and professional lives.

In his Nobel Lecture, titled Crediting Poetry, delivered in 1995, Seamus Heaney eloquently presents a perspective on poetry that acknowledges the ways that words are integrally connected to worlds:

The form of the poem, in other words, is crucial to poetry's power to do the thing which always is and always will be to poetry's credit: the power to persuade that vulnerable part of our consciousness of its rightness in spite of the evidence of wrongness all around it, the power to remind us that we are hunters and gatherers of values, that our very solitudes and distresses are creditable, in so far as they, too, are an earnest of our veritable human being. (29)

Heaney credits poetry "because credit is due to it, in our time and in all time, for its truth to life, in every sense of that phrase" (12). It is this "truth to life" that I am eager to pursue. I agree with Susan Griffin's claim that "poetry does not describe. It is the thing. It is an experience, not the second-hand record of an experience, but the experience itself" (191). 
Regarding the processes of writing poetry, I am especially struck by Sara Mills' claim, significantly informed by Michel Foucault, that "there is no intrinsic order to the world itself other than the ordering which we impose on it through our linguistic description of it" (52). Mills explains that "discourses structure both our sense of reality and our notion of our own identity" (15). If, in postmodern understanding, our knowledge of the world and reality is always shaped and constituted in discursive structures, then from educational perspectives, it is important to acknowledge how curricular disciplines, such as history, geography, literature, science, and mathematics, are all connected to discourses that represent sites for "constant contestation of meaning" (Mills, 16). Since "discursive rules are always under constant negotiation and renegotiation" (Mills, 98), and because it is people who use and negotiate and contest discursive structures and conventions, then each of us is inextricably caught up in the processes of learning, questioning, and challenging identity, subjectivity, memory, desire, and ideology. In effect, each one of us is involved in the constitution and reconstitution of discursive structures, and hence we are all caught up in the relentlessly imperative enterprise of epistemology with its core question of how we know what we know. As Jed Rasula and Steve McCaffery suggest, "to invent a language is potentially to invent a world" (49). Because, as Mills explains, "the process of finding a position for oneself within discourse is never fully achieved, but is rather one of constantly evaluating and considering one's position and, inevitably, constantly shifting one's perception of one's position and the wider discourse as a whole" (97), then we are all always caught up in a dynamic, creative contest amidst constantly evolving discourses. And so, quite simply, there is room for understanding and promoting poetry as a discursive structure for informing, shaping, and guiding our living and learning experiences. Heaney explains his poetic process: "I had already begun a journey into the wideness of the world. This in turn became a journey into the wideness of language, a journey where each point of arrival — whether in one's poetry or one's life - turned out to be a stepping stone rather than a destination" (11). So, what is poetry good for? I offer five ruminations for generating dialogue about why poetry is relevant and significant for life and living.

\section{POETRY IS PROPHETIC.}

I recently read Walter Brueggemann's The Prophetic Imagination, and I was moved by Brueggemann's understanding of the work of the ancient prophets of Israel, including Moses, Isaiah, and Jeremiah. Brueggemann claims that "imagination is indeed a legitimate way of knowing" (x). According to Brueggemann, while "prophetic imagination ... is concerned with matters political and social ... it is as intensely concerned with matters linguistic (how we say things) and epistemological (how we know what we know)" (21). In a twist on the title phrase, prophetic imagination, Brueggemann also refers to poetic imagination as "the last way left in which to challenge and conflict the dominant reality" (40). Brueggemann objects to the frequent and facile rejection of the potential political significance of poetry:

It is only a poem, and we might say rightly that singing a song does not change reality. However, we must not say that with too much conviction. The evocation of an alternative reality consists at least in part in the battle for language and the legitimization of a new rhetoric. The language of the empire is surely the 
language of managed reality, of production and schedule and market. But that language will never permit or cause freedom because there is no newness in it.

Winterson asks, "Can we afford to live imaginatively, contemplatively? Why have we submitted to a society that tries to make imagination a privilege when to each of us it comes as a birthright?" (139) I agree with Winterson that "if we want a living language, a language capable of expressing all that it is called upon to express in a vastly changing world, then we need men and women whose whole self is bound up in that work with words" (36). And like Winterson, I am convinced that "for the writer, serving the much maligned Muse seems to be the best way of serving society" (36). The American poet Jay Parini was invited by Laura Bush to participate in a White House symposium on poetry. Bush cancelled the symposium when she learned that some of the invited poets might protest the war in Iraq. Subsequently, in an essay titled "A Time for Poets to Raise Their Voices," Parini asks some tough questions about poets and politics. He notes that "poets are people who have spent a lot of time thinking about the relationships between words and things; they have thought about language and its applications and directions. They often feel a sense of responsibility when it comes to speech, and troubled when it seems insufficient to the realities around them" (B20). After considering the examples of several poets, including Walt Whitman, Emily Dickinson, and Langston Hughes, Parini concludes:

There is a place where poetry and politics converge, but it's a zone of complexity and nuance. Poetry at its best is always a frank, pained, sometimes elated expression of reality. It discovers and contemplates injustice. It laments poverty: that of imagination as much as physical poverty. It asks readers to imagine what has happened, and - perhaps more important - to imagine what might follow. (B20)

We are born into relations with others, relations that have been inscribed by dynamics of politics and economics and history and education and religion, and we are defined by those relations, even as we seek to define ourselves as other, as different, as unique. There is an ongoing tension to clear a space for our unique performances, even at the same time we know that we are inextricably connected to others, to many others. Poetry is one more way of questioning and reconstituting our knowing and becoming and living in the world.

\section{POETRY IS HEALING.}

In a world of heartache, precipitated by violence, war, poverty, and greed, I propose simply that we can transform the world by writing poetry. I identify, at least a little, with some of the experiences of the American native poet, Sherman Alexie, who writes: "Growing up on a reservation, in poverty, in what we would learn only later to call dysfunction, I never found much use for poetry" (Ciuraru 33). While I do not personally know the persistent marginalization, poverty, and dysfunction that Alexie writes about, I grew up in a working class home in a mill town, and, like Alexie, "I could not find anything familiar in poetry and felt small and insignificant in its presence" (Ciuraru 33). 
Then, finally, in my later twenties, during a passage of personal crisis, as part of a healing process, I began to write poetry, and discovered how a poem can shape words and compose locations for imagining worlds.

Winterson contends that "the healing power of art is not a rhetorical fantasy" (156), and she understands with characteristic insight that "in a self-destructive society like our own, it is unsurprising that art as a healing force is despised" (157). I admire Polly Thompson's claim that "each poem is a construct against dissolution" (160). In my daily living, I am motivated by the conviction that in words I know, I am known, I am. Because I am constructed in language, interpellated into subjectivity by my relationship to language, I am always seeking to be constructed further in language - to be fulfilled, perhaps even attributed a measure of authority or purpose. Writing is not self-expression; instead, writing is self-construction. Jasper Neel suggests that "the last thing apt to happen in writing is 'self-discovery.' Instead, what happens in writing is a forever becomingpresent" (124). As I seek to make sense out of the chaos of emotions and experiences and thoughts that swirl around my head without end, I am constantly reminded that my life is inextricably intertwined with language, rhetoric, and literary device whereby I disclose (and conceal) what I know about the world and my experience in it. I am caught up in language, in word-making, in meaning-making, constantly striving to create the world, or at least a sense of place in the world. Like Kingsolver, "my way of finding a place in this world is to write one" (233). Writing is then "about finding a way to be alive" (Kingsolver, 233). Writing does not enable the writer to hammer down secure truth; writing enables the writer to explore possibilities for meaningful living in the world. As Barry Cameron claims:

Through language, we imagine everything and everyone, we invent everything and everyone, we remember everything and everyone-including ourselves. Insofar as experience is available for comment, insofar as it has meaning, insofar as it is present to us - immediately in front of us now-it is available only as fiction: fingere (to shape or to make). (71)

Instead of ignoring poets and poetry, we need to understand how poetry is integral to human living. Wallace Stevens claims that "Life consists/Of propositions about life" (76), and that "The whole race is a poet that writes down/The eccentric propositions of its fate" (76). For too long, poetry has been constituted as a discourse that either marginalizes or is marginalized. In other words, poets are either rendered a little god-like or are roundly ignored. Poetry has been too long understood as the privileged purview of a few, and so poetry has been too frequently ignored or rejected as not connected to human life. I agree with Kingsolver that "we live in a culture that doesn't put much stock" in poetry (230). She observes, "I don't know of a single American poet who ever made a living solely by writing poetry" (230). And yet, Kingsolver understands how poems fall "from the richly pollinated boughs of an ordinary life, buzzing, as lives do, with clamor and glory. They are easy to miss but everywhere: poetry just $i s$, whether we revere it or try to put it in prison. It is elementary grace, communicated from one soul to another" (231).

POETRY IS LUDIC. 
Maxine Hong Kingston presents a playful perspective on poetry in To Be the Poet: "The Poet truly lives the happening moment, and gives the very bodily feeling of it to whosoever would read. To put myself into the state of poetry, I need to learn the habit of living constantly within the present moment" (10-11). While engaging in writing a poem, Kingston notes: "I was already living the Poet's life. I came to rest. I took the time to be still, to be with friends, to behold them, to observe where I am, to have feelings, whatever the feelings might be .... The Poet alights in the right-now time, and stays in the special ordinary moment. If I were to make an hour for poetry every day, I would change my life" (30-31). Kingston is promoting the notion that poetry and poets focus on attending to living in the moment, on seeking stillness and solitude, on revelling in joyful encounters with the world. She writes:

I am in bewitchment to change everything into words

By day, writing, enwording ... What's the urgency?

The use? The good of it? $\ldots$ only pleasure .... (86)

In their provocative book, Imagining Language: An Anthology, Jed Rasula and Steve McCaffery explain how "social communication is not rule-bound or subject to decree and regulation, but is consolidated in the ad hoc spirit of play" (49-50). And it is this play that Kingston emphasizes, a ludic abandonment in the moment. Of course, poets know that in this precise commitment to playfulness lies the creative energy for lively protest, dynamic innovation, and imagined alternatives.

In a related way, Maurice Blanchot writes about Foucault:

Foucault is a man always on the move, alone, secretive, and who, because of that, distrusts the marvels of interiority, refuses the traps of subjectivity, asking where and how there emerges a discourse entirely surface and shimmering, but bereft of mirages - a discourse not alien to the search for truth, as was believed, but one that finally reveals the perils of that search and its ambiguous relations with the myriad configurations of power. (68)

In Blanchot's description of Foucault I find a useful description of the activity and knowledge of the poet. When I name myself or when I am named by others, I am created (constructed or written) with identities, and these identities are multiple because I always occupy many subject positions - including teacher, poet, father, husband, believer, Newfoundlander. I have written myself and been written in multiple identities.

Sometimes these identities are conflictual, possibly even contradictory, constantly in a process of change, malleable and tentative. When I consider that everyone I meet is like me in that we are all constituted in the play of language, always writing and being written in changing configurations, I wonder how we ever communicate about anything.

We always live with multiple subjectivities, but we generally conceal the multiplicity behind a few predictable and typical guises. Poetry invites us to explore the plural identities of human be(com)ings constituted in the play of language. I like Kingsolver's suggestion: "In my opinion, when you find yourself laughing and crying both at once, that is the time to write a poem. Maybe that's the only honest living there is" (234). We all need to be committed to writing and re-writing our stories together. 


\section{POETRY IS MEDITATIVE.}

Canadian poet John Steffler asks:

What, ideally, can poetry offer that other types of writing cannot offer, or at least not so directly or purely? It seems to me that at its best - and this is what we search for in poems all the time - poetry approximates, through the powerful use of language, our fundamental, original sense of life's miraculousness, its profound and mysterious meaning. (47)

Steffler notes that "poetry is a readiness for intensity and acuity and surprise" (48). The poet always understands that she or he is located in a complex space and time. The poet's perspective entails a zeal for attending, and questioning, and believing. Steffler understands that "poetry is first of all a state of mind. Before it's a verbal structure, it's a way of perceiving and interacting with the world, including oneself, one's own life" (48). Like Steffler, Kingsolver explains: "I rarely think of poetry as something I make happen; it is more accurate to say that it happens to $m e$ " (229). Poets "generally allow that there's magic involved, and that the main thing is to pay attention" (Kingsolver, 230).

Poetry is about rhythm (from the Greek rhythmos): measure or measured motion. Rhythm is the relation of part to part and of parts to the whole. It is balance, the flowing of blood, breath, breathing, not breath-taking but breath-giving. Rhythm is the measure of speech, of the heart, of dancing, of the seasons, knowing the living word, the energy of language to inscribe, inspirit hope, even in the midst of each day's wild chaos.

Gisela Labouvie-Vief presents a useful perspective on philosophy as constructed in Western scholarship:

Western intellectual tradition has brought us a separation of two aspects of mind and self. On the one hand, there is the realm of logos - the realm of logic and objectivity, of all that can be stated in terms of rational truths, of our hope that life can be reduced to laws that are mechanical and precise. On the other hand, there is the realm of mythos - the realm of all that is felt and organic, of all that appeals to the inner world of emotions, of our tendency to leap out of the constraints of analytical precision and to seize the novel. (1)

Virginia Woolf echoes this perspective: "I feel that strong emotion must leave its trace; and it is only a question of discovering how we can get ourselves again attached to it, so that we shall be able to live our lives through from the start" (67). As Woolf suggests, poetry involves seeking ways to attach ourselves to strong emotion. As a poet, I know that I live consciously and constantly in my emotions. I am seeking to live poetically, and that means living emotionally with my feelings in motion and commotion. But who can I share these emotions with? Who can receive the intensity of these emotions?

I am reminded of a striking poem by Al Pittman titled "What My Father Said About Sound." Pittman explores: "How to describe the sound/of the sea in a way you can/carry in your pocket/or in your head!" (119). The narrator of the poem confesses, "The sounds the sea makes/are the sea's alone./They do not belong to poets or musicians" (119), and 
concludes, "This is a good thing./It will keep the poets/and musicians struggling/as long as there are poets/and musicians to struggle" (119). In a related way, Steffler explains:

What poetry offers, then, is not a form of abstract, quantifiable knowledge, like scientific findings, that can be amassed and advanced. Instead, through the convenient portability of words, it offers a semblance of direct experience, a recovery or approximation of emotional experience that engages our sense of the numinous and the aesthetic. It reorganizes and deepens our awareness of our past experience and kindles our appetite for future experience. It sharpens our sense of vitality and mortality. (49)

\section{POETRY IS FULL OF TRUTH.}

Winterson understands that "the language poets use is and is not the language that all of us use. For a poet a word carries in itself an abundance of meanings" (80). Rasula and McCaffery refer to "the stubborn autonomy of poetic language" (119). For Winterson, "the language of a poet" is "heightened, exact, using rhythm not logic as its anchor" (87). Truth is not a commodity to be packaged and dispensed in neat portions. Perhaps it is not untrue to suggest that each one of us is the truth - at least as much of the truth as can be identified. Not the truth in an empirical, objective way, but subjects interpellated in language, in meaning-making, constantly striving to create the world. As Neel understands, "writing promises truth, but all the while writing defers truth in order to keep the promise, and not its fulfullment, in operation" (133). Writing does not enable the writer to hammer down secure truth, but it does enable the writer to explore possibilities of meaning. And that openness is what poets practice.

With a subtly engaging insight Susan Griffin explores the meaning of poetry:

What is it that makes poetry different than prose? It is said that poetry has rhyme, and rhythm, and line breaks, that it uses metaphor. But these distinctions have never seemed sufficient to me. They seem instead only to be symptomatic of a deeper-lying purpose. It is said that prose is rational and poetry is not. And yet, on one level, poetry is quite rational. The poem may seem irrational because, like a dream, it ignores the boundaries we accept as real. In a dream I can be several people at once - myself, my father, a child, a woman pregnant. And this is also true in a poem. In the poem one can have the direct experience of being in two places at once, feeling two opposite emotions, holding two contradictory opinions, at once. And of course, one can. This is the real nature of the mind. Poetry is closer to that nature than prose. (189)

With the resonances of Griffin's words, I turn to Heidegger who claims that "poetry proper is never merely a higher mode (melos) of everyday language. It is rather the reverse: everyday language is a forgotten and therefore used-up poem, from which there hardly resounds a call any longer" (208). For Heidegger, then, "the opposite of what is purely spoken, the opposite of the poem, is not prose. Pure prose is never 'prosaic.' It is as poetic and hence as rare as poetry" (208). And so, as a language educator, my commitment is simply, but irrevocably, to seek the anima, the spirit, the energy that is at the heart of all discourse. Poetry calls attention to itself as a rhetorical structure, as a 
discursive practice. Where prose is often perceived as a transparent window on reality, poetry is opaque. Poetry invites readers to slow down. Poetry invites us to listen. Poetry is a site for dwelling. I agree with Derrida's suggestion that "every poem has its own language, it is one time alone its own language, even and especially if several languages are able to cross there" (409). A poem is a textual site where a diversity of languages, emotions, and perspectives can be entertained.

As Heidegger claims, "to be a poet in a destitute time means: to attend, singing, to the trace of the fugitive gods. This is why the poet in the time of the world's night utters the holy" (94). This is not some grandiose, egocentric claim that poets are superior beings on the planet, a little more god-like than everybody else. Simply, poetry is a discursive structure with practices and conventions that render it flexible and malleable. I am not suggesting that prose as a discursive structure lacks the possibility of flexibility. Not at all. I am suggesting only, and I hope modestly, that poetry is the discursive structure that is most readily characterized by experimentation, invention, and pushing boundaries. As a reviewer wrote recently about some of my poems, "These poems do not surprise or startle." Clearly the reviewer believed that poetry ought to surprise and startle. Now, I could certainly challenge the reviewer's understanding of poetry, and cite Sara Mills, for example, to support a claim that the reviewer is caught up in an inflexible conception of what a poem is and can be. But all poets and critics and literary scholars and literature teachers (including me in this essay) are enmeshed in claims about the nature of poetry, claims that can be deconstructed and reconstructed, using the same language that is available for all discussions and definitions and designations. For example, Michael Ondaatje claims that "in writing, especially in poetry, you are always trying to find ways to forge alliances between unlikely things, striking juxtapositions, finding the right shorthand for ideas, metaphors" (34). I am struck by Ondaatje's definition of writing, and poetry in particular, as "striking juxtapositions." I eagerly agree with Ondaatje, of course, but, still, I don't think that Ondaatje's definition is more than one possible and insightful perspective. Truth is always polyvalent and changing.

So, I turn to Heidegger again with his helpful advice:

Truth, as the clearing and concealing of what is, happens in being composed, as a poet composes a poem. All art, as the letting happen of the advent of the truth of what is, is, as such, essentially poetry. The nature of art, on which both the art work and the artist depend, is the setting-itself-into-work of truth. It is due to art's poetic nature that, in the midst of what is, art breaks open an open place, in whose openness everything is other than usual. (72)

I resonate with Heidegger's notion that "the nature of art ... is the setting-itself-into-work of truth": the notion that truth is composed in the open places broken open by art.

Heidegger focuses on how art calls forth the unfamiliar. And so this is why I recommend that writing poetry is crucial to sustaining a creative flexibility in language and discourse, and hence the composing of truth in our living. I seek in poetry to live open to the surprises of language. Instead of parroting the received wisdom of the dominant political and cultural machine, I will be interrogative, skeptical, agnostic even, readily acknowledging that what I know is that there is so much I do not know. Again I agree with Heidegger that "the poetic is the basic capacity for human dwelling" (228). 
Wallace Stevens writes about "The magnificent cause of being,/The imagination, the one reality/In this imagined world" (15). Poetry is the place where the unimaginable can be imagined. So, I draw these ruminations to a close, hopefully a tentative, even a temporary, close, with a recent poem written in response to living sabbatically in York Harbour, Newfoundland. The poem is not intended to be necessarily representative of the themes of this essay, though it might indeed be so, but more significantly, I include the poem in the hope that it will perform with some of the dynamic energy of poetry that Wendell Berry writes about: "The poem is important,/as the want of it/proves. It is the stewardship/of its own possibility" (21).

\section{BEACHSTONES}

to see what is really there and to record it

as it is-without dramatizing or striving for effect

(D.R. Cowles, Canadian photographer)

$\&$

in the Wiseman's house

at the end of Main Street

in York Harbour faraway

on the North Atlantic edge

I am slowly learning

how to live sabbatically,

drawing silence

like the sun calls the sea

$\&$

winter hasn't yet arrived

in York Harbour where

autumn has been a long

weekend without end,

but I'm sure snow will

come soon with poems

like spiced apple cider

$\&$

somebody named the trees

in the boreal forest that clings

to the Long Range Mountains

with simple descriptors,

black spruce, white pine, black ash,

white birch, red maple, yellow birch,

but another with a poet's eye 
called one tree trembling aspen, the only one I can identify

$\&$

winter arrived today

wrapped in windy whispers,

enough to stop the heart

in the circle of long months, and the harbour seems smaller, with snow, mist, and low clouds in the mountains and sea

like winter shrinks everything

$\&$

while I revised this poem the oil furnace stopped blowing, and Sam the Irving's repairman is on his way, hopefully soon, since on this winter's day, I am Bob Cratchit scratching figures in Ebenezer Scrooge's accounts, and I don't want to whine, but this poem is failing to keep us warm

$\&$

in the tangled midst of memories, the heart is resilient and calls out for a poet's language with the breath of dark moist rum-soaked fruit cake like Lana just made for Christmas

$\&$

silence falls like March snow, full of surprises seen in the window

$\&$

in York Harbour

I am learning to live with a different measure, but how can I practise 
rural rhythms amidst the urgent urban rhythms of Vancouver far from the midnight, moonlight winter sky subtended with geometric whimsy by an arc of the Atlantic

$\&$

after hauling lobster traps near Little Port Head fishermen return in a dory, pumpkin orange with green gunwales, and sea gulls chase the boat, a flume of spray like a tail on a kite, raucous calling for scraps the fishermen might leave

$\&$

the dandelions close up at night and in rain, then spring open yellow hearts in the sun

$\&$

I want to stand naked in the spring rain

and grow like daffodils open to language

$\&$

June 21, the first day of summer, fog and rain, capelin weather, went for a walk and wore gloves, turned the thermostat up, still no sign of summer

$\&$ 
in this place the sun rises

in the harbour, and light

and shadow are the alphabet

that composes the senses

and poems for sustaining

stillness and stability

$\&$

like the countless beachstones

that line York Harbour

I can't tell you the stories

I have lived in this place,

still clutching the wild

chaotic world in my words

\section{WORKS CITED}

Berry, Wendell. Entries. New York: Pantheon Books, 1994.

Blanchot, Maurice. Michel Foucault as I Imagine Him. Trans. Jeffrey Mehlman. New York: Zone Books, 1990.

Brueggemann, Walter. The Prophetic Imagination. $2^{\text {nd }}$ ed. Minneapolis: Fortress Press, 2001.

Cameron, Barry. John Metcalf. Boston: Twayne, 1986.

Ciuraru, Carmela, ed. First Loves: Poets Introduce the Essential Poems That Captivated and Inspired Them. New York: Scribner, 2000.

Derrida, Jacques. Acts of Literature. Ed. Derek Attridge. New York: Routledge, 1992.

Griffin, Susan. The Eros of Everyday Life: Essays on Ecology, Gender and Society. New York: Doubleday, 1995.

Heaney, Seamus. Crediting Poetry. Loughcrew: The Gallery Press, 1995.

Heidegger, Martin. Poetry, Language, Thought. Trans. Albert Hofstadter. New York:

Harper and Row, 1971.

Kingsolver, Barbara. Small Wonder: Essays. New York: HarperCollins, 2002.

Kingston, Maxine Hong. To Be the Poet. Cambridge: Harvard UP, 2002. 
Labouvie-Vief, Gisela. Psyche and Eros: Mind and Gender in the Life Course. Cambridge: Cambridge UP, 1994.

Mills, Sara. Discourse. London: Routledge, 1997.

Milosz, Czeslaw. The Witness of Poetry. Cambridge: Harvard UP, 1983.

Neel, Jasper. Plato, Derrida, and Writing. Carbondale: Southern Illinois UP, 1988.

Ondaatje, Michael. The Conversations: Walter Murch and the Art of Editing Film. Toronto: Vintage Canada, 2002.

Parini, Jay. "A Time for Poets to Raise Their Voices." The Chronicle of Higher Education. 49.27 (2003): B20. (http://chronicle.com)

Pittman, Al. "What My Father Said About Sound." An Island in the Sky: Selected Poetry of Al Pittman. Ed. Martin Ware and Stephanie McKenzie. St. John's: Breakwater Books, 2003. 119-120.

Rasula, Jed, and Steve McCaffery (ed.). Imagining Language: An Anthology. Cambridge: MIT Press, 1998.

Steffler, John. "Language as Matter." Poetry and Knowing: Speculative Essays \& Interviews. Ed. Tim Lilburn. Kingston: Quarry Press, 1995. 45-51.

Stevens, Wallace. Selected Poems. London: Faber and Faber, 1953.

Thompson, Polly. "Pat's Poem." Writing Right: Poetry by Canadian Women. Ed. Douglas Barbour and Marni L. Stanley. Edmonton: Longspoon, 1982. 160-161.

Winterson, Jeanette. Art Objects: Essays on Ecstasy and Effrontery. Toronto: Alfred A. Knopf Canada, 1995.

Woolf, Virginia. Moments of Being. Ed. Jeanne Schulkind. New York: Harcourt Brace Jovanovich, 1976. 